\title{
Evaluation of Aster bakerianus Burtt Davy ex C.A. Sm. Crude Root Extract for Acute Antiinflammatory Activity in Rats
}

\author{
Sibusisiwe Magama ${ }^{1}$, Asita Okorie Asita ${ }^{1}$, \\ Teboho Derrick Skundla ${ }^{1}$
}

${ }^{1}$ Department of Biology, National University of Lesotho, P.O. Roma 180 Maseru, Lesotho, Southern Africa

\begin{abstract}
The crude extract of Aster bakerianus roots used for treatment of a variety of ailments in Lesotho was evaluated for anti-inflammatory activity and phytochemical content. Extract was first tested for toxicity at oral dosages of 0 (negative control), 1000, 2000, 3000 and $5000 \mathrm{mg} / \mathrm{kg}$ bw with five groups of female mice, each group having four mice. Negative control group received sterile distilled water $(1.0 \mathrm{ml} / \mathrm{kg} \mathrm{bw})$. Mice were observed for general symptoms of toxicity for 24 hours and left for a further 14 days for any delayed toxicity. None of the extract doses induced toxicity. Anti-inflammatory activity of A. bakerianus was determined using the carrageenan-induced rat paw oedema assay. Five groups of six mice each were orally pre-treated as follows: Negative control group (group 1) received sterile distilled water $(1.0 \mathrm{ml} / \mathrm{kg} \mathrm{bw})$. Positive control group (group 2) received indomethacin $(10 \mathrm{mg} / \mathrm{kg} \mathrm{bw})$. Three test groups (group 3, 4 and 5) received A. bakerianus extract, 100, 200 and $400 \mathrm{mg} / \mathrm{kg} \mathrm{bw}$ respectively. After one hour of pre-treatment, all test groups and controls were injected with $0.1 \mathrm{ml}$ carrageenan subcutaneously in the right hind paw and paw thicknesses recorded at the following time intervals: $0,1,2,3,4,5,6$, and 24 hours. Statistically $(\mathrm{p}<0.05)$ there was no difference observed in the antiinflammatory activity profile of $A$. bakerianus and that of the drug indomethacin at the different time intervals of the study, implying same efficacy. The anti-inflammatory activity of extract was attributed to presence of terpenoids, saponins, sterols, simple phenols, coumarins, polyphenols, flavonoids, tannins, phlobatannins, anthocyanins, alkaloids, glycosides and amino acids. The results of this study justified the documented use of this plant by Basotho for treatment of inflammatory disorders.
\end{abstract}

Keywords: Eicosanoids, Cyclooxygenase, Phytochemicals, Indomethacin, Rat Paw Diameter

\section{Introduction}

Acute inflammation is a rapid, short-lived initial response of tissue to harmful stimuli (such as injury) initiated by cells constituting the relevant tissues (Ambriz-Pérez et al., 2016) and is characterised by accumulation of fluid, plasma proteins and the leukocytes which release a large number of soluble inflammatory mediators which are responsible for the initiation, progression, persistence, modulation (regulation) and eventual resolution of the acute state of inflammation (Oguntibeju, 2018; Nguyen et al., 2020). The classical signs of acute inflammation include oedema, erythema, pain, heat, and primarily loss of function of the affected part of the body (Nathan, 2002; Husein et al., 2012).

The acute inflammatory process involves a cascade of biochemical events comprising the local vascular system, the immune system and different cell types found in the injured tissue (Kulinsky, 2007). Numerous proinflammatory mediators are released during an inflammatory response, including the vasoactive amines; histamine, serotonin, bradykinin
(Kulinsky, 2007; El-Shitany et al., 2014) and the cytokines, interleukin $1 \beta$ (IL-1 $\beta$ ), IL-6, IL-8, IL-12, tumour necrosis factor- $\alpha$ (TNF- $\alpha$ ) and interferon- $\gamma$ $(\mathrm{INF}-\gamma)$ as well as prostaglandins especially PGE2 through cyclooxygenase-2 (COX-2), leukotrienes through lipooxygenase (LOX), nitric oxide (NO) through the inducible nitric oxide synthase (iNOS) (Husein et al., 2012; Kulinsky, 2007; El-Shitany et al., 2014). Also released is the nuclear factor kappa B $(\mathrm{NF}-\kappa \mathrm{B})$, a transcription factor that plays an important role in the transcription of genes, as it induces transcription of its target genes such as COX2 , iNOS, TNF- $\alpha$, IL-1 $\beta$, and IL- 6 , chemokines and adhesion molecules (Karin \& Ben-Neriah, 2000) that cause acute inflammation (Nguyen et al., 2020). The cytokines play major roles in the initiation and amplification of inflammatory processes (Calixto et al., 2004). Nitric oxide (NO), a free radical generated by inducible nitric oxide synthase (iNOS), can act as a defence and regulatory molecule with homoeostatic activities; however, it can also be detrimental when produced excessively (Xiong et al., 2000; Husein et al., 2012). Inflammatory reactions are supposed to

This article is published under the terms of the Creative Commons Attribution License 4.0 Author(s) retain the copyright of this article. Publication rights with Alkhaer Publications. Published at: http://www.ijsciences.com/pub/issue/2020-09/

DOI: 10.18483/ijSci.2377; Online ISSN: 2305-3925; Print ISSN: 2410-4477 

in Rats

lead to either the resolution of tissue injury or complete eradication of pathogens in the body in case of infection (Husein et al., 2012). However, when the process of inflammation is not completely resolved, it can be detrimental to tissues and the body as a whole (Ben et al., 2016).

The different reactions in the inflammatory response cascade are therapeutic targets, which antiinflammatory agents including medicinal plants interfere with to suppress exacerbated inflammatory responses usually invoked in such disorders as injury, rheumatoid arthritis and infection (Iwueke et al., 2006). Any interruption of the inflammatory sequence of events results in the reduction of the liberation of the mediators causing the microcirculation to come back to normal hemodynamic state (Danya, 2017).

Conventionally, inhibitors of proinflammatory cytokines and cyclooxygenase (COX) enzymes such as the nonsteroidal antiinflammatory drug (NSAID) indomethacin, is currently the choice of antiinflammatory agents (Lucas, 2016). The NSAIDs block prostaglandin and thromboxane formation by inhibiting cyclooxygenase activity (Danya 2017) and inhibit the NF- $\kappa$ B pathway and various inflammationassociated genes (Yamamoto \& Gaynor (2001). However, these drugs, proven to be effective in many cases, can cause undesirable side effects to some degree (Lucas, 2016) and in some instances exhibit low potency (Husein et al., 2012; Talluri et al., 2016; Oguntibeju, 2018). The development of safer and efficacious alternative anti-inflammatory agents is therefore necessary (Ponmathi et al., 2017; Rajanandhini \& Musthafa 2017; Sathiyabalan et al., 2018) hence the increase in studies on plant derived medicines and on creation of herbal formulations that could be used in the treatment of inflammatory diseases with less or no side effects (Talluri et al., 2016; Ponmathi et al., 2017; Rajanandhini \& Musthafa 2017; Sathiyabalan et al., 2018; Oguntibeju, 2018). Also, traditional medicines derived from plant extracts are increasingly being used to treat a wide variety of diseases; many being prescribed broadly for the treatment of inflammatory conditions though relatively little knowledge about their mode of action is available (Amala Hazel et al., 2018; Oguntibeju, 2018). While plant derived antiinflammatories are rarely as immediately effective as the steroidal antiinflammatory drugs and NSAIDs, they are very rarely as toxic nore potentially life threatening (Talluri et al., 2016; Oguntibeju, 2018).

Research studies on medicinal plants used in traditional medicine represents a suitable approach for the development of new drugs (Ullah et al., 2014). Herbal medicine has been recognised by the World
Health Organisation (WHO) as an important component of primary health care and as such efforts are being made to combine its therapeutic potential with that of orthodox medicine (Kaur and Jaggi, 2010). The WHO considers phytotherapy in its health programs and suggests basic procedures for the validation of drugs from plant origin in developing countries (Ullah et al., 2014) and the carrageenan induced oedema model for acute peripheral inflammation is one of the in vivo models approved. Medicinal plants have therefore become the subject of intense pharmacological studies in the last few decades (Fernandes \& Banu, 2012; Oguntibeju, 2018).

Many plant species have shown potential for antiinflammatory activities (Oguntibeju, 2018) due to the presence of a wide variety of phytochemicals that can be a source of anti-inflammatories themselves and could also be used for the discovery of novel antiinflammatory agents with fewer side effects (Talluri et al., 2016; Oguntibeju, 2018). The chemical compounds present in plant products are a part of the physiological functions of living organisms, and hence they are believed to have better compatibility with the human body (Prasad et al., 2012). The therapeutic potential of any herbal drug depends on its form; whether it is part of a plant, or isolated active constituents or crude extracts containing several constituents, which often work together synergistically (Bandaranayake, 2006).

In the Kingdom of Lesotho, two forms of health-care systems are used; namely the traditional system and the orthodox western system. Traditional medicine plays a vital role in the quest for well-being of the rural population in Lesotho, particularly where there is limited accessibility to clinics or health facilities (Seleteng-Kose et al., 2019; Shale et al., 1999).

Aster bakerianus (Asteraceae) is widely distributed in Southern Africa and is one of the important medicinal plants widely used by the Basotho in the Kingdom of Lesotho (Moteetee \& Seleteng-Kose, 2017; Oguntibeju, 2018) for the treatment of a variety of ailments. In the local dialect of Lesotho (Sesotho) $A$. bakerianus is called phooa, and its roots are used to treat a number of ailments (van Wyk et al., 1997; van Wyk et al., 1997). The denser cluster of roots, each of which is elongated and tapering on both ends (fusiform), is generally used in traditional medicine (van Wyk et al., 1997). As a traditional remedy for headache, the dried roots of $A$. bakerianus are powdered and used as snuff to induce sneezing (Hutchings and van Staden, 1994). The roots may also be pounded and mixed with water to clean the nostrils. A. bakerianus is also used locally for the 

in Rats

treatment of snake-bites, asthma, venereal diseases, syphilis, urinary infections, anthrax, eye infections, stomach aches, colic, psychiatric disorders, shortsightedness and intestinal parasites (van Wyk et al., 1997). The liquid from crushed boiled roots is taken in doses of a teaspoonful once a day for chronic coughs or in larger doses as an emetic and have a purgative action (van Wyk et al., 1997).

According to Moteetee and Seleteng-Kose (2017), A. bakerianus has not yet been evaluated for antiinflammatory activity, and to date no other literature was found on anti-inflammatory activity of $A$. bakerianus hence this study.

The relationship between traditional use of a plant species and inflammatory processes has been studied using several species (Agnihotri et al., 2010; Ishola et al., 2014; Popoola et al., 2016). The carrageenaninduced rat paw oedema is used widely as a standard experimental model of aseptic acute inflammation (Di Rosa et al., 1971; Ponmathi et al., 2017; Danya 2017) used in the search for and evaluation of new orally active anti-inflammatory drugs or natural products (Amala Hazel et al., 2018; Panthong et al., 2007) which act through mediators of acute inflammation (Ben et al., 2016; Kumar and Jain, 2014), test new anti-inflammatory drugs for their potency, study the mechanisms involved in acute inflammation (Hassimotto et al., 2013; Khakimov et al., 2019) and evaluate NSAIDs and appears to have been the basis for the discovery of indomethacin (Falodun et al., 2006; Danya 2017). Moreover, this experimental model exhibits a high degree of reproducibility (Di Rosa \& Sorreatino, 1968). In this method, reduction in paw oedema in this triphasic model is a good indicator of the protective effect of an anti-inflammatory substance (Rizvi et al., 2014; Rajanandhini \& Musthafa 2017). Carrageenan induced rat paw aseptic inflammation oedema leads to an increase in the production of NO, PGE2, TNF$\alpha$, and IL- 6 in plasma, and also an increase in the expression of iNOS, COX-2, TNF- $\alpha$, and IL-6 in paw tissue during the late phase of acute peripheral inflammation due to activation of the nulear factor kappa B (Salvemini et al., 1996; Hussein et al., 2012; Talluri et al., 2016).

\section{Materials and Methods}

\subsection{Chemicals}

Indomethacin (Sigma-Aldrich, St Louis, MO, USA), carrageenan (Sigma, USA), Lambda-carrageenan Type IV (Sigma Chemical Co., St. Louis, USA), digital analytical balance, sodium chloride (Associated Chemical Enterprises (Pty) Ltd., Johannesburg, South Africa), methanol (Associated Chemical Enterprises (Pty) Ltd., Johannesburg, South Africa), micropipettes (Eppendorff), $1.0 \mathrm{ml}$ hypodermic syringes, sterile single use (Promex, Jhb, RSA), vernier calipers micrometer (0150mm/0.02mm; Mitutoyo, Japan).

\subsection{Plant Material}

The whole plant of Aster bakerianus was collected at Ha Nkhema village located north east of the National University of Lesotho Roma Campus with the following co-ordinates: $29^{\circ} 26^{\prime} 56^{\prime \prime} \mathrm{S}, 27^{\circ} 43^{\prime} 18^{\prime \prime}$, E. Altiude: $1683 \mathrm{~m}$ above sea level. The roots were obtained by digging-out the whole plant after which the roots were separated and used in the study. The plant was authenticated by the herbarium curator $(\mathrm{Mr}$. M. Polaki) of the Department of Biology, National University of Lesotho. A voucher specimen of the $A$. bakerianus plant was deposited in the herbarium in the Department of Biology.

\subsection{Preparation of crude extract of A. bakerianus roots}

The soil-free roots of Aster bakerianus were gently washed in distilled water and dried in an oven (Labcon) equipped with a fan at $35{ }^{\circ} \mathrm{C}$ for two days and then ground to fine powder with a pestle and mortar (Magama et al., 2017). The powdered material $(40 \mathrm{~g})$ was extracted with $400 \mathrm{ml}$ methanol $(95 \% \mathrm{v} / \mathrm{v}$ in distilled water) for 72 hours at room temperature on an orbital shaker at speed of 120 rotations per minute. The extract was then filtered under suction and the filtrate was concentrated to about a quarter of its original volume under vacuum in a Gallenkamp (Germany) rotary evaporator (Magama et al., 2017). The resultant crude extract was then dried in the oven (Labcon) with fanning at $35{ }^{\circ} \mathrm{C}$ until brittle which took 72 hours. The dried extract was stored at $4{ }^{\circ} \mathrm{C}$ until use.

\subsection{Animals}

Inbred 20 female nulliparous and non pregnant mice of NIH strain albino mice ranging from 8-12 weeks and weighing between $22-24 \mathrm{~g}$ were used in the toxicity assay and 36 male Adult Wistar Albino rats between 8-12 weeks old and weighing between 150 and $200 \mathrm{~g}$ were used in the carrageenan-induced ratpaw oedema model for acute inflammation. The animals were bred and kept in the animal house of the Department of Biology and allowed free access to food (meadow sheep pellets) and water ad-libitum.

\subsection{Toxicity assay}

The method of the Organization for Economic Cooperation and Development-423 (OECD-423) guidelines (2002) dosing schedule was used to determine the acute oral toxicity of A. bakerianus root extract. Briefly, Twenty (20) healthy female 

in Rats

albino mice NIH strain ranging from 8-12 weeks old nulliparous and non pregnant, were obtained from the National University of Lesotho animal house, Department of Biology. The animals were then randomly selected and divided into four groups of four mice each $(\mathrm{n}=4)$. Prior to testing, the animals were fed classic horse feed (12\% maintenance cubes) and had free access to drinking water but were starved for 12 hours before testing. After oral administration with different fixed single dosages of the A. bakerianus root extract; 1000, 2000, 3000 and $5000 \mathrm{mg} / \mathrm{kg}$ body weight and sterile distilled water in the control group using a bulb-ended steel needle, the animals were observed for any toxicological signs and symptoms, and mortality continuously for 1 hour and then hourly for 6 hours and finally after every 24 hours up to 14 days altogether for any delayed toxicity manifestations such as modifications of the skin, the hairs (piloerection), eyes, motor activity and behavior. Emphasis was on the observation of various manifestations of toxicity such as tremors, convulsions, salivation, diarrhoea, lethargy, piloerection, lacrimation, nasal secretion, cyanosis, sleep, coma and mortality (N'Goka et al., 2018; Zahra et al., 2020).

\subsection{Acute inflammation test}

For the determination of the anti-inflammatory activity of the crude extract of $A$. bakerianus roots, the following safe oral doses were used: 100, 200 and $400 \mathrm{mg} / \mathrm{kg}$ bw., which were $1 / 10$ for the first two and $1 / 12.5$ of the $4^{\text {th }}(5000 \mathrm{mg} / \mathrm{kg} \mathrm{bw})$ doses used in the acute toxicity tests. In this study, the in vivo acute anti-inflammatory activity of $A$. bakerianus root extract was evaluated using the inhibition of carrageenan-induced rat hind paw oedema test used in many similar studies (Winter et al., 1962; Rodrigues et al., 2016; Sathiyabalan et al., 2018). Five groups of six male albino Wistar rats per group (groups 1-5) were set-up in six metal cages and maintained at $26 \pm 2{ }^{\circ} \mathrm{C}$ with free access to food and water.

The animals were orally administerd with $A$. bakerianus crude root extract (groups 3,4,5 at 100, 200 and $400 \mathrm{mg} / \mathrm{kg}$ bw respectively) and indomethacin $10 \mathrm{mg} / \mathrm{kg}$ bw (group 2) (Rodrigues et al., 2016; Sathiyabalan et al., 2018). The negative control group (group 1) was orally given $1.0 \mathrm{~mL} / \mathrm{kg}$ bw $\mathrm{H}_{2} \mathrm{O}$ (Husein et al., 2012). After one hour of oral administration of the test samples (different doses of A. bakerianus root extact) and controls (positive control :indomethacin and negative control sterile distilled water); $0.1 \mathrm{ml}$ of $1 \%(\mathrm{w} / \mathrm{v})$ carrageenan suspension in normal saline $(0.9 \% \quad \mathrm{w} / \mathrm{v} \mathrm{NaCl})$ solution was injected into the sub-plantae tissue of the right hind paw of the animals in groups 1 to 5 for the induction of acute inflammation (Husein et al.,
2012; Sathiyabalan et al., 2018; Khakimov et al., 2019). The needle was inserted to a depth of approximately $1 \mathrm{~mm}$ into the callus to deliver an accurate and uniform amount of carrageenan into the subplantar tissue (Ishola et al., 2014).

The different groups were pre-treated orally as follows:

Group 1: Distilled water, vehicle of drug $(1 \mathrm{ml} / \mathrm{kg}$ bw) + carrageenan injection $s c$ after 1 hour (negative control)

Group 2: Indomethacin (10 mg/kg bw $)+$ carrageenan injection $s c$ after 1 hour (positive control)

Group 3: A. bakerianus extract $(100 \mathrm{mg} / \mathrm{kg} \mathrm{bw})+$ carrageenan injection $s c$ after 1 hour

Group 4: A. bakerianus extract $(200 \mathrm{mg} / \mathrm{kg} \mathrm{bw})+$ carrageenan injection $s c$ after 1 hour

Group 5: A. bakerianus extract $(400 \mathrm{mg} / \mathrm{kg} \mathrm{bw})+$ carrageenan injection $s c$ after 1 hour

The linear paw thickness (dorso-ventral diameter) for each rat was measured before aseptic injection of carrageenan and after injection of carrageenan (Ponmathi et al., 2017) using a vernier callipers at 0 $\mathrm{hr}$, then at hourly intervals for six hours, at 1, 2, 3, 4, 5, 6 hours (Bamgbose \& Noamesi, 1981) and finally at the 24th hour (Husein et al., 2012; Ganesh et al., 2013; Ishola et al., 2014; Khakimov et al., 2019) post $s c$ injection. The increase in paw thickness was taken as an indicator of the degree of acute inflammation. The mean oedema value of each root extract treated group (group 3, 4 and 5) and the indomethacin treated group (group 2) was compared with that of the negative control group (group 1).

Anti-inflammatory activity was calculated as a percentage (\%) inhibition of paw oedema when the drug indomethacin (or the root extract) was present, relative to the negative control (Group 1) as follows: Percentage $(\%)$ inhibition of paw oedema $=\left(V_{c^{-}}-V_{t}\right) / V_{c}$ $\times 100$

Where:

$V c$ is the inflammatory increase in paw thickness in control group of animals (Group 1, given only the vehicle of both drug and extract),

$V t$ is the inflammatory increase in paw thickness in drug (or extract) treated animals.

\subsection{Qualitative phytochemical tests}

The qualitative tests for relevant phytochemical classes in the crude methanolic extract of $A$. bakerianus roots were performed according to Thilagavathi et al., 2015; Gul et al., 2017; Bharathi \& Udayakumar (2019). The following classes were tested for: Flavonoids (Thilagavathi et al., 2015; Gul et al., 2017), Terpenoids (Bharathi \& Udayakumar, 2019), Phenolics (Bharathi \& Udayakumar, 2019), 
Evaluation of Aster bakerianus Burtt Davy ex C.A. Sm. Crude Root Extract for Acute Antiinflammatory Activity in Rats

Glycosides (Thilagavathi et al., 2015; Gul et al., 2017; Bharathi \& Udayakumar, 2019), Tannins (Thilagavathi et al., 2015; Bharathi \& Udayakumar, 2019), Coumarins (Bharathi \& Udayakumar, 2019), Alkaloids (Thilagavathi et al., 2015), Phytosterols (Thilagavathi et al., 2015), Reducing sugars (Thilagavathi et al., 2015). The results were noted as either negative (-) meaning not detected because either absent or below the detection limit) or positive (+) for the particular class of compounds. If positive, the colour intensity was classified as + for low intensity, ++for medium intensity, +++ for high intensity.

\subsection{Data analysis}

Results for evaluation of $A$. bakerianus root extract for anti-oedematogenic activity were expressed as the mean value \pm standard deviation of the mean paw thickness. Treated groups were compared with the controls for statistically significant differences between the means of each group of 6 rats. $(p<0.05)$ using paired Student's $t$-test and the Tukey multiple comparisons analysis of variance. Statistical differences with $\mathrm{P}<0.05$ were considered significant.

\section{Results}

The yield of the crude root extract from the dried powdered roots of A.bakerianus roots after extraction with $95 \%$ Methanol (v/v) in distilled water was $8.62 \%$.

\subsection{Toxicity test for $A$. bakerianus crude root extract}

At the oral dosage range of $A$. bakerianus crude root extract (1000-5000 $\mathrm{mg} / \mathrm{kg} \mathrm{bw})$ at which mice were challenged with the extract, no symptoms of toxicity in mice were observed at all dosages of the extract during the 14 days of monitoring, therefore the $\mathrm{LD}_{50}$ was estimated to be higher than $5000 \mathrm{mg} / \mathrm{kg}$ bw.

Table 1: Toxicity signs observed in mice treated with oral doses of A. bakerianus root extract

\begin{tabular}{|c|c|c|c|c|c|}
\hline \multirow[t]{2}{*}{ Parameters } & \multirow{2}{*}{$\begin{array}{l}\text { Control group } \\
\text { Sterile distilled } \\
\text { water }\end{array}$} & \multicolumn{4}{|c|}{ Aster bakerianus root extract } \\
\hline & & Test group 1 & Test group 2 & Test group 3 & Test group 4 \\
\hline Doses & $20 \mathrm{ml} / \mathrm{kg}$ bw & $1000 \mathrm{mg} / \mathrm{kgbw}$ & $2000 \mathrm{mg} / \mathrm{kgbw}$ & $3000 \mathrm{mg} / \mathrm{kg}$ bw & $5000 \mathrm{mg} / \mathrm{kgbw}$ \\
\hline Behaviour & $\mathrm{N}$ & $\mathrm{N}$ & $\mathrm{N}$ & $\mathrm{N}$ & $\mathrm{N}$ \\
\hline Mobility & $\mathrm{N}$ & $\mathrm{N}$ & $\mathrm{N}$ & $\mathrm{N}$ & $\mathrm{N}$ \\
\hline Condition of stools & $\mathrm{C}$ & $\mathrm{C}$ & $\mathrm{C}$ & $\mathrm{C}$ & $\mathrm{C}$ \\
\hline Convulsion & $\mathrm{A}$ & A & $\mathrm{A}$ & $\mathrm{A}$ & $\mathrm{A}$ \\
\hline Tremor & $\mathrm{A}$ & $\mathrm{A}$ & $\mathrm{A}$ & $\mathrm{A}$ & $\mathrm{A}$ \\
\hline Sleep & $\mathrm{A}$ & $\mathrm{A}$ & $\mathrm{A}$ & $\mathrm{A}$ & $\mathrm{A}$ \\
\hline Hair appearance & $\mathrm{N}$ & $\mathrm{N}$ & $\mathrm{N}$ & $\mathrm{N}$ & $\mathrm{N}$ \\
\hline Aspect of the skin & $\mathrm{N}$ & $\mathrm{N}$ & $\mathrm{N}$ & $\mathrm{N}$ & $\mathrm{N}$ \\
\hline Condition of eyes & $\mathrm{N}$ & $\mathrm{N}$ & $\mathrm{N}$ & $\mathrm{N}$ & $\mathrm{N}$ \\
\hline
\end{tabular}

$\mathrm{N}=$ Normal, $\mathrm{A}=$ Absent, $\mathrm{C}=$ Compact

\subsection{Weight Progression}

The mice of groups 1, 2, 3, and 4 were treated orally with doses of 1000, 2000, 3000 and $5000 \mathrm{mg} / \mathrm{kg}$ bw of methanolic root extract of A. bakerianus respectively. The mice of the control group were treated orally with sterile distilled water. The daily weighings of mice during the 14 days of testing for acute toxicity were used to monitor weight progression of the treated and control mice. Figure 1 shows the daily percentage $(\%)$ changes in weight for the 14 day study period for acute toxicity. The treated animals gained weight in a dose dependent manner though they were given the same feed. There was no significant $(p<0.05)$ difference in increase in the weight of the mice within groups and between groups compared to the control during the 14 day period of the acute toxicity study in the ANOVA Tukey multiple comparisons. 

in Rats

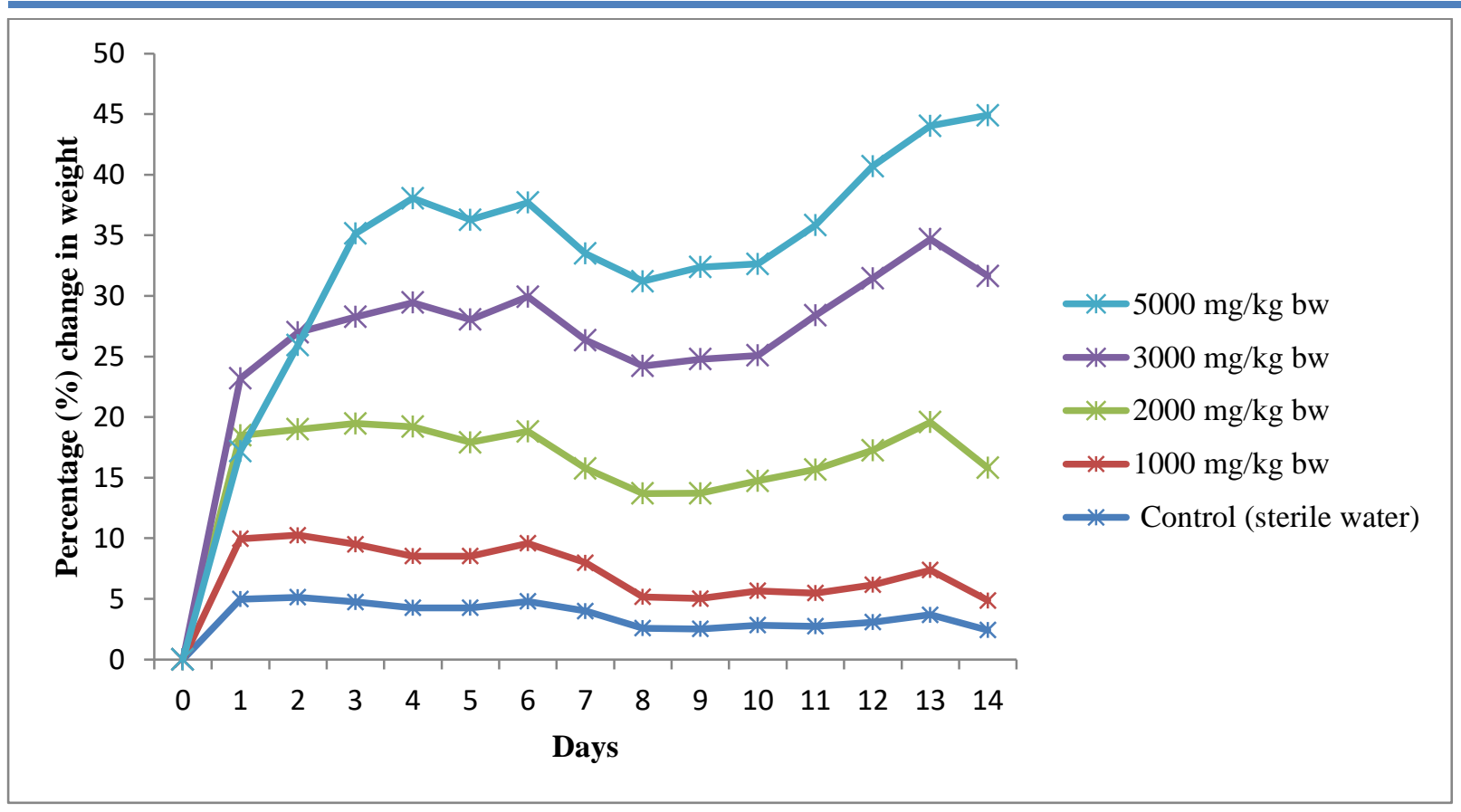

Figure 1: Daily percentage (\%) change in mean mass of mice following oral administration with methanolic extracts of $A$. bakeranus and sterile water. $\mathrm{n}=4$ for each group, $\mathrm{p}<0.05$ compared to the control group.

\subsection{Antiinflammatory activity of $\boldsymbol{A}$. bakerianus crude root extract}

In Table 1 is presented the results of comparison of mean rat paw thicknesses $(\mathrm{mm} \pm \mathrm{SD})$ of the indomethacin treated group (2) and each extract treated test groups (3-5) with the negative control (group 2) as well as between test groups themselves, at the seven different time intervals of the experiment and percent inhibition of inflammation in groups 2, 3, 4,5 and 6 at the time intervals $0,1,2,3,4,5,6$ and 24 hours.

Subcutaneous injection of the rat paw with carrageenan without treatment (group 1) as shown in Table 2 induced a time-dependent progressive inflammatory oedema which was recorded as mean paw thickness with a peak during the period from 4 till 6 hours as follows: at 1 hour: $6.31 \pm 0.84 \mathrm{~mm}$, at 2 hours: $6.87 \pm 0.64 \mathrm{~mm}$, at 3 hours: $6.78 \pm 0.67 \mathrm{~mm}$, at 4 hours: $7.50 \pm 1.13 \mathrm{~mm}$, at 5 hours : $7.47 \pm 1.57 \mathrm{~mm}$, and at 6 hours: $7.59 \pm 1.15 \mathrm{~mm}$ post carrageenan injection. After the $6^{\text {th }}$ hour, a very slight resolution of the inflammation continued till the end of the experiment at 24 hours $(7.24 \pm 0.67 \mathrm{~mm})$. The increases in paw thickness were less pronounced in the indomethacin and extract treated groups (groups 2-5) than in the negative control (vehicle) treated group (group 1). With reference to the negative control group, it was observed that from the time of subcutaneous injection of the rat paw with carrageenan, up to 2 hours post injection, there was an increase in paw thickness which plateaeud slightly between 2 and 3 hours then began to increase again up till 6 hours and remaining high despite an insignificant deacrese observed at 24 hours (Table 2 and Figure 2). This pattern of the graph was depressed in the treated groups (groups 25).

The results (Table 2) showed that all three test extract doses $(100,200$ and $400 \mathrm{mg} / \mathrm{kg}$ bw) of A. bakerianus root extract protected the rats from carrageenan induced inflammation and the three test extract doses showed a moderate anti-inflammatory activity in a time and dose dependent manner during the period of study. All three doses of the extract and indomethacin induced a significant $(p<0.05)$ timeand dose-dependent inhibitory effect against carrageenan-induced acute peripheral inflammation in the rat paw when compared with the water treated (vehicle) negative control group (group 1) at 1, 2, 3, 4, 6 and 24 hours except at the 5 hour time interval. The inhibitory effects were statistically the the same for both A. bakerianus root and the drug indomethacin treated groups at each of the time intervals and highest during the period of 4-6 hours than during the period 1-3 hours post carrageenan injection. Reduction of paw thickness or oedema (as an indication of reduction in acute inflammation) by the different doses of the crude extract of $A$. bakerianus roots $(100,200$, and $400 \mathrm{mg} / \mathrm{kg} \mathrm{bw})$ and the drug indomenthacin $(10 \mathrm{mg} / \mathrm{kg} \mathrm{bw})$ was observed to be statistically similar $(\mathrm{p}<0.05)$ in the Tukey's multiple comparisons analysis using ANOVA at all doses and time intervals as shown in Table 2. There 

in Rats

was therefore no statistically significant difference in anti-inflammatory activity between indomethacin and the $A$. bakerianus extract at all time intervals and doses of the extract used in this study.

In Figure 1 is presented the curves of the changes in paw thickness with time for the three concentrations of A.bakerianus root extract (groups 3-5) and the reference drug indomethacin (group 2). As shown on the graphs, treatment with extracts and indomethacin gave more depressed curves than the negative control group 1 treated with the vehicle, distilled water.

Table 2: Group $(\mathrm{n}=6)$ mean of rat paw thickness $(\mathrm{mm}) \pm \mathrm{SD}$ after oral administration with different dosages of $A$. bakerianus extract $(100,200,400 \mathrm{mg} / \mathrm{kg} \mathrm{bw})$, indomethacin $(10 \mathrm{mg} / \mathrm{kg} \mathrm{bw})$ and distilled water $(1 \mathrm{ml} / \mathrm{kg} \mathrm{bw})$, followed one hour later by subcutaneous injection with $0.1 \mathrm{ml}$ carrageenan solution in saline.

\begin{tabular}{|c|c|c|c|c|c|c|}
\hline \multirow[b]{3}{*}{ Time (Hrs) } & \multicolumn{5}{|c|}{ Oral Treatments } & \multirow{3}{*}{$\begin{array}{l}\text { Time } \\
\text { Interval } \\
\text { F Values }\end{array}$} \\
\hline & \multirow[b]{2}{*}{$\begin{array}{l}\text { Distilled water } \\
(1 \mathrm{ml} / \mathrm{kg} \mathrm{bw})\end{array}$} & \multirow[b]{2}{*}{$\begin{array}{l}\text { Indomethacin } \\
(10 \mathrm{mg} / \mathrm{kg} \mathrm{bw})\end{array}$} & \multicolumn{3}{|c|}{ Aster bakerianus root extract (mg/kg bw) } & \\
\hline & & & 100 & 200 & $\begin{array}{l}\text { Interval } \\
\text { F Values }\end{array}$ & \\
\hline 0 & $\begin{array}{l}3.15 \pm 0.19 a \\
0.00 \S \\
(0.00)\end{array}$ & $\begin{array}{l}5.33 \pm 0.28 b \\
0.00 \S \\
(-68.92)^{*}\end{array}$ & $\begin{array}{l}4.90 \pm 0.61 \mathrm{~b} \\
0.00 \S \\
(-55.39)^{*}\end{array}$ & $\begin{array}{l}5.38 \pm 0.61 b \\
0.00 \S \\
(-70.49)\end{array}$ & $\begin{array}{l}5.12 \pm 0.39 b \\
0.00 \S \\
(-62.26)^{*}\end{array}$ & $40.455 ¥$ \\
\hline 1 & $\begin{array}{l}6.31 \pm 0.84 \mathrm{~b} \\
50.00 \S \\
(0.00)\end{array}$ & $\begin{array}{l}6.09 \pm 0.32 \mathrm{~b} \\
12.58 \S \\
(3.38) \\
\end{array}$ & $\begin{array}{l}6.58 \pm 0.57 b \\
25.49 \S \\
(-4.28) \\
\end{array}$ & $\begin{array}{l}6.27 \pm 0.38 \mathrm{~b} \\
14.29 \S \\
(0.55) \\
\end{array}$ & $\begin{array}{l}5.80 \pm 0.54 \mathrm{ab} \\
11.83 \S \\
(7.98) \\
\end{array}$ & $7.153 ¥$ \\
\hline 2 & $\begin{array}{l}6.87 \pm 0.64 \mathrm{~b} \\
54.08 \S \\
(0.00)\end{array}$ & $\begin{array}{l}6.38 \pm 0.42 \mathrm{ab} \\
16.51 \S \\
(7.08)^{*}\end{array}$ & $\begin{array}{l}6.67 \pm 0.78 b \\
26.46 \S \\
(2.96)\end{array}$ & $\begin{array}{l}6.74 \pm 0.24 b \\
20.24 \S \\
(1.85)\end{array}$ & $\begin{array}{l}6.08 \pm 0.60 \mathrm{abc} \\
15.80 \S \\
(11.50)^{*}\end{array}$ & $4.689 ¥$ \\
\hline 3 & $\begin{array}{l}6.78 \pm 0.67 b \\
53.49 \S \\
(0.00)\end{array}$ & $\begin{array}{l}6.56 \pm 0.53 \mathrm{ab} \\
18.84 \S \\
(3.20) \\
\end{array}$ & $\begin{array}{l}6.66 \pm 0.60 \mathrm{~b} \\
26.39 \S \\
(1.82)\end{array}$ & $\begin{array}{l}6.74 \pm 0.52 \mathrm{ab} \\
20.24 \S \\
(0.59)\end{array}$ & $\begin{array}{l}6.22 \pm 0.71 \mathrm{ab} \\
17.74 \S \\
(8.26)\end{array}$ & $2.941 ¥$ \\
\hline 4 & $\begin{array}{l}7.50 \pm 1.13 b \\
57.94 \S \\
(0.00)\end{array}$ & $\begin{array}{l}6.86 \pm 0.43 \mathrm{ab} \\
22.39 \S \\
(8.45) \\
\end{array}$ & $\begin{array}{l}6.74 \pm 0.57 \mathrm{ab} \\
27.30 \S \\
(10.09) \\
\end{array}$ & $\begin{array}{l}6.78 \pm 0.562 \mathrm{ab} \\
20.66 \S \\
(9.61) \\
\end{array}$ & $\begin{array}{l}6.62 \pm 0.51 \mathrm{ab} \\
22.71 \S \\
(11.69)^{*}\end{array}$ & $3.641 ¥$ \\
\hline 5 & $\begin{array}{l}7.47 \pm 1.57 \mathrm{bcd} \\
57.77 \S \\
(0.00) \\
\end{array}$ & $\begin{array}{l}6.49 \pm 0.58 \text { acd } \\
17.97 \S \\
(13.04) \\
\end{array}$ & $\begin{array}{l}6.69 \pm 0.70 \text { acd } \\
26.72 \S \\
(10.45) \\
\end{array}$ & $\begin{array}{l}6.63 \pm 0.45 \mathrm{bcd} \\
18.89 \S \\
(11.23) \\
\end{array}$ & $\begin{array}{l}6.20 \pm 1.00 \text { acd } \\
17.43 \S \\
(17.01) \\
\end{array}$ & $2.315 £$ \\
\hline 6 & $\begin{array}{l}7.59 \pm 1.15 b \\
58.44 \S \\
(0.00)\end{array}$ & $\begin{array}{l}6.64 \pm 0.66 \mathrm{ab} \\
19.78 \S \\
(12.48)^{*} \\
\end{array}$ & $\begin{array}{l}6.90 \pm 0.77 \mathrm{ab} \\
28.99 \S \\
(9.05) \\
\end{array}$ & $\begin{array}{l}6.9 \pm 0.53 \mathrm{ab} \\
22.04 \S \\
(9.10)\end{array}$ & $\begin{array}{l}6.64 \pm 0.73 \mathrm{ab} \\
22.98 \S \\
(12.43)\end{array}$ & $3.447 ¥$ \\
\hline 24 & $\begin{array}{l}7.24 \pm 0.67 \mathrm{~b} \\
56.45 \S \\
(0.00)\end{array}$ & $\begin{array}{l}6.73 \pm 0.86 \mathrm{~b} \\
20.84 \S \\
(7.00)^{*}\end{array}$ & $\begin{array}{l}7.09 \pm 0.69 \mathrm{~b} \\
30.92 \S \\
(2.03)\end{array}$ & $\begin{array}{l}6.99 \pm 0.48 \mathrm{~b} \\
23.07 \S \\
(3.48)\end{array}$ & $\begin{array}{l}6.77 \pm 0.4 \mathrm{~b} \\
24.40 \S \\
(6.52) \\
\end{array}$ & $7.116 ¥$ \\
\hline
\end{tabular}

$\S=$ Percent $(\%)$ changes in paw thickness;

()$=$ Numbers in parenthesis are percent $(\%)$ inhibition of oedema;

$*$ = Percent $(\%)$ inhibition of oedema was significantly different $(\mathrm{p}<0.05$ in the $\mathrm{t}$-test $)$ compared to the negative control (saline);

$¥=$ There is a significant difference in the Mean inhibition values of oedema at the given time interval of the different treatments $\left(\mathrm{F}_{5,29}=2.54, \mathrm{P}<0.05\right)$

$£=$ There is no difference in the Mean inhibition values of oedema at the given time interval of the different treatments $\left(\mathrm{F}_{5,29}=2.54, \mathrm{P}>0.05\right)$

$\mathrm{a}, \mathrm{b}, \mathrm{c}, \mathrm{d}=$ Group Means of inhibition of oedema with the same letter at any given time interval do not differ statistically $(\mathrm{p}<0.05)$ in the Tukey multiple comparisons analysis. 
Evaluation of Aster bakerianus Burtt Davy ex C.A. Sm. Crude Root Extract for Acute Antiinflammatory Activity in Rats

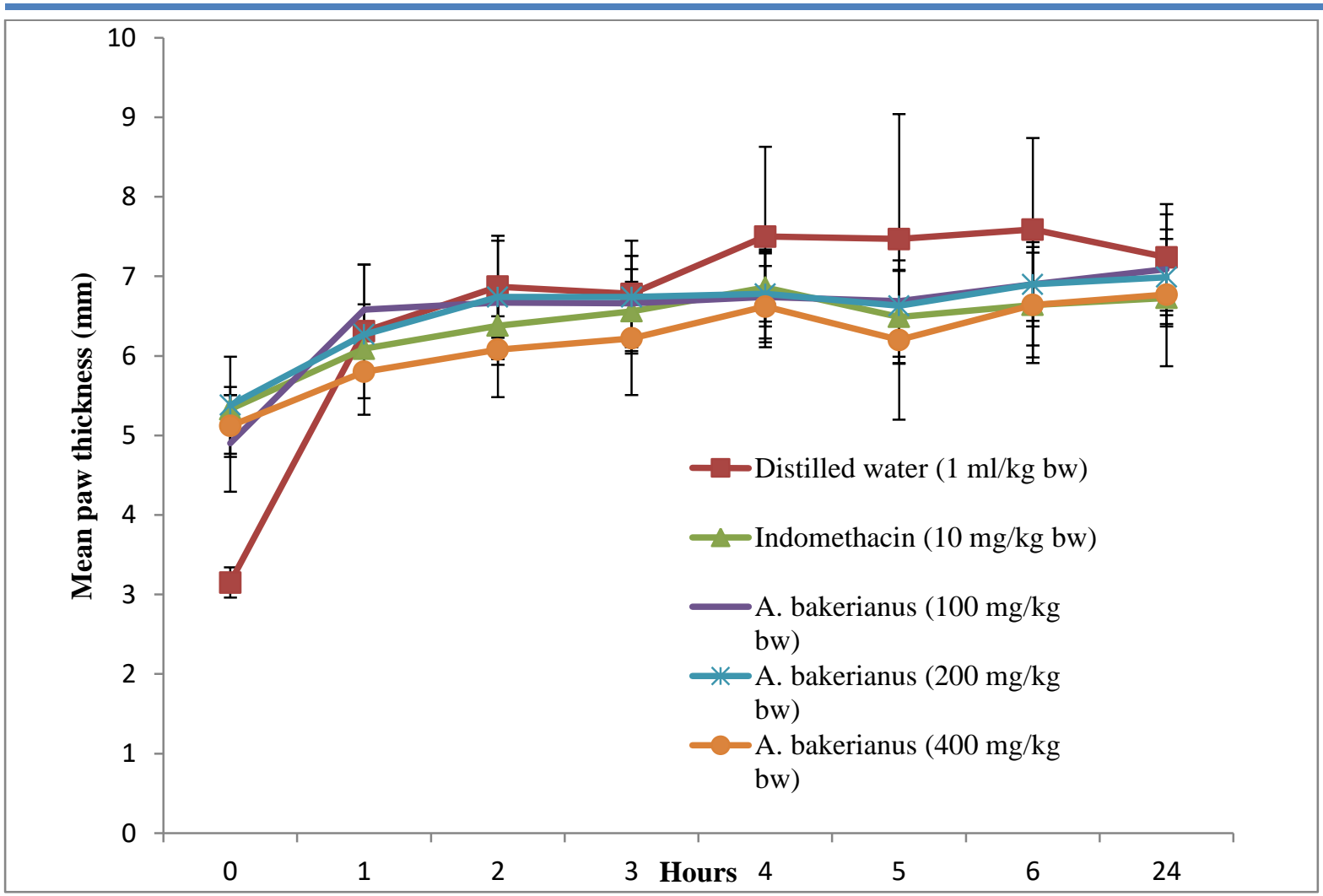

Figure 2: Changes in paw thickness after oral administration of different dosages of A. bakerianus extract and controls followed an hour later by s.c. injection with carrageenan solution.

\subsection{Qualitative phytochemical tests}

The phytochemical classes identified in the root extract are presented in Table 3. The relevant phytochemical constituents detected qualitatively in the crude root extract of $A$. bakerianus were mostly phenolics; both simple phenols $(+++)$ and polyphenols $(+++)$ including the flavonoids $(+++)$, tannins $(+++)$, phlobatannins $(+++)$, anthocyanins $(+++)$, betacyanins, coumarins $(+++)$. Also present in high intensities were the terpenoids $(+++)$, saponins $(+++)$, phytosterols $(+++)$, amino acids (+++), reducing sugars $(+++)$. In lower intensities were the glycosides $(++)$ and traces $(+)$ of alkaloids.

Table 3: Qualitative phytochemical profile of methanolic extract of $A$. bakerianus root extract

\begin{tabular}{|l|l|l|}
\hline Phytochemical class & Test & $\begin{array}{l}\text { Positive } \\
(+) / \text { Negative } \\
(-)\end{array}$ \\
\hline Alkaloids & Wagner & + \\
\hline Flavonoids & Shinoda & +++ \\
\hline Saponins & Foam/froth test & +++ \\
\hline Tannins & $\begin{array}{l}\text { Ferric } \\
\text { chloride/Braymer's } \\
\text { test }\end{array}$ & +++ \\
\hline Terpenoids & Salkowski & +++ \\
\hline Simple phenols & Ferric chloride & +++ \\
\hline Polyphenols & Ferric chloride & +++ \\
\hline Sterols & $\begin{array}{l}\text { Salkowski/Chloroform } \\
\& \text { conc H2SO4 }\end{array}$ & +++ \\
\hline
\end{tabular}

\begin{tabular}{|l|l|l|}
\hline Glycosides & Fehling's & ++ \\
\hline Quinones & $\mathrm{HCl}$ & - \\
\hline Phlobatannins & $\mathrm{HCl}$ & +++ \\
\hline Coumarins & $\mathrm{NaOH}+$ Chloroform & +++ \\
\hline Anthocyanins & $\mathrm{NaOH}$ & +++ \\
\hline Betacyanins & $\mathrm{NaOH}$ & +++ \\
\hline Reducing sugars & Benedict's & +++ \\
\hline Amino acids & Ninhydrin & +++ \\
\hline Proteins & Biuret & - \\
\hline
\end{tabular}

Key: $(-)=$ Negative; $(+)=$ Positive: $+=$ low colour intensity, $++=$ medium colour intensity, $+++=$ high colour intensity

\section{Discussion}

In this study, the crude methanolic extract of $A$. bakerianus roots used in traditional medicine in the Kingdom of Lesotho for the treatment of various ailments was evaluated for acute toxicity and acute anti-inflammatory activity on the basis of inhibition of carrageenan-induced rat hind paw oedema. The presence of oedema is one of the major signs of inflammation and paw oedema volume has been increasingly used to test new anti-inflammatory drugs (Kumar \& Jain, 2014).

In the acute toxicity study, six groups of five mice each were orally administered with sterile distilled water, indomethacin and the following four doses of the crude methanolic extract of $A$. bakerianus roots 

in Rats

(1000, 2000, 3000 and $5000 \mathrm{mg} / \mathrm{kg}$ body weight). No sign of toxicity (such as convulsions, ataxy, diarrhoea, increased diuresis) or mortality, in any of the groups therefore the median lethal dose (LD50) of the $A$. bakerianus roots extract was considered to be higher than the highest dose, $5000 \mathrm{mg} / \mathrm{kg}$ bw. The mice gained weight in a dose dependent manner (Figure 1) even though all groups were fed the same food and water ad libitum. The fact that the $\mathrm{LD}_{50}$ of the extract was above $5000 \mathrm{mg} / \mathrm{kg}$ bw, this was an indication that the extract could be considered as nontoxic, when adimistered orally. In a similar study for acute toxicity, N'Goka et al., 2018 reported that extracts of Vitex madiensis administered orally did not cause any acute toxicity even at $5000 \mathrm{mg} / \mathrm{kg} \mathrm{bw}$. All the doses of $A$. bakerianus root extract caused statistically significant $(\mathrm{p}<0.05)$ increases in body mass at the different time intervals compared to the negative control, with the highest increase being induced by $5000 \mathrm{mg} / \mathrm{kg}$ during the 14 days of acute toxicity test. The extract was rich in amino acids and phytosterols (Table 3). It has been proven that phytosterols increase body mass and amino acids are required for growth too (Nsonde Ntandou et al., 2015). This effect could therefore be explained by the presence of the phytosterols in the methanolic extracts (N'goka et al., 2018).

The oral doses of $A$. bakerianus root extract used in the anti-inflammatory tests were chosen as 400 $\mathrm{mg} / \mathrm{kg} \mathrm{bw}, 200 \mathrm{mg} / \mathrm{kg}$ bw and $100 \mathrm{mg} / \mathrm{kg}$ bw, these being much lower than the LD50.

As shown in Table 2 and in Figure 2, group 1 (negative control) rats, it was observed that from the time of $s c$ injection with carrageenan, up to 2 hours post injection, there was an increase in paw thickness which slightly plateaued between 2 and 3 hours. Then, from the $3^{\text {rd }}$ hour, it began to increase again remaining high till 24hours. The peak period of carrageenan-induced inflammation was from 4 hours. The changes (increases) in paw thickness in group 1 rats (the negative control group), at the different time intervals as shown in Table 2 were as follows: at 1 hour, 50\%; at 2 hours, $54.08 \%$; at 3 hours, $53.46 \%$; at 4 hours, $57.94 \%$; at 5 hours, $57.77 \%$; at 6hours, $58.44 \%$ and at 24 hours to $56.45 \%$. The period of maximum paw oedema was from 4 to 24 hours in the untreated group 1. A depressed, similar pattern was observed in the treated groups (groups 2-5). Based on such observations the initiation and progression of oedema after subcutaneous injection of carrageenan into the rat paw has been described as being triphasic and acute (Ishola et al., 2014; Talluri et al 2016 ; Kumar \& Jain, 2014; Birhane et al., 2014; Popoolaa et al., 2016)., The phases of inflammatiory oedema were demarcated as follows: early phase $(0-2$ hours) (Talluri et al., 2016), intermediate phase (2-3 hours) Talluri et al., 2016), late phase (3-24 hours) (Talluri et al., 2016; Ishola et al., 2014). The early phase is mainly mediated by histamine and serotonin starts immediately after injection of carrageenan while the intermediate phase provides continuity between the early phase and the late phase and is mediated by kinins, mainly bradykinin (Ishola et al., 2014; Popoola et al., 2016). The late phase is associated with release of prostaglandins, leukotrienes and NO with increased expression of COX-2 and iNOS which are influenced by the nuclear factor kappa B (NF-кB) (Di Rosa et al., 1971; Sidhapuriwala et al., 2007) and also the release of protease, lysosomes, and migration of leukocytes into the inflamed site occurs during the late phase of oedema (Talluri et al., 2016). It has been reported that the suppression of carrageenan induced hind paw oedema after the fourth hour correlates reasonably with therapeutic doses of most clinically effective anti-inflammatory drugs, both steroidal and non steroidal such as indomethacin (Panthong et al., 2007; Kumar \& Jain, 2014). In our study, this suppression of of carrageenan-induced oedeama by $A$. bakerianus roots extract and indomethacin was maximal during the period from 4 hours to 6 hours post carrageenan injection corresponding to the late phase of inflammation.

The efficacy of A. bakerianus root extract and that of indomethacin were statistically $(\mathrm{p}<0.05)$ in this study. The trend observed in our study was in agreement with observations by other authors using the carrageenan test for acute inflammation. Sarada et al., 2012 studied the leaf and bark of extract of Naringi crenulata at oral doses of 250 and $500 \mathrm{mg} / \mathrm{kg}$ bw and reported that the pattern of anti-inflammatory activity and percent inhibition in paw volume induced by these extracts was similar to that of indomethacin $(10 \mathrm{mg} / \mathrm{kg}$ bw p.o.) which, to these authors suggested that, the activity of the leaf and bark extracts of Naringi crenulata used in the study could be mediated by $\mathrm{COX}-1$ and $\mathrm{COX}-2$ inhibition since indomethacin is a COX-1 and COX-2 inhibitor. In another study the oral doses $150 \mathrm{mg} / \mathrm{kg}$ and 300 $\mathrm{mg} / \mathrm{kg}$ of ethanol extracts of Barleria courtallica prepared from stem, root and leaf produced significant inhibition of carrageenan induced paw oedema at 3 rd hour comparable to that brought about by the reference drug indomethacin $(10 \mathrm{mg} / \mathrm{kg} \mathrm{bw})$ (Ponmathi et al., 2017). Rodrigues et al., 2016 observed that indomethacin was effective at reducing oedema at all time intervals of a 5 hour study with maximum activity at 5 hours in the same way as oral doses of Ocimum basilicum oil (100 and $50 \mathrm{mg} / \mathrm{kg}$ bw p). In a similar study, Ishola et al., 2014 observed that oral administration of methanol root extracts of 

in Rats

Alafia barteri, Combretum mucronatum, and Capparis thonningii (100-200mg/kgbw) produced dose-related and time dependent significant suppression of carrageenan-induced inflammation in the middle and late phases when compared with the vehicle-treated negative control group with peak inhibition from the $3 \mathrm{rd}$ to the 24 th hour at $200 \mathrm{mg} / \mathrm{kg}$ p.o. treatment. Other reported studies of depression of carrageenan-induced rat paw acute inflammation include studies with methanolic extracts of $C$. rottleri root, leaf and stem at $125 \mathrm{mg} / \mathrm{kg}, 250 \mathrm{mg} / \mathrm{kg}$ and $500 \mathrm{mg} / \mathrm{kg}$ bw by Talluri et al., 2016. These doses significantly inhibited the maximal paw edema response during the 6 hours study of the carrageenaninduced rat paw acute inflammation together with the standard inflammatory drug, indomethacin the authors were still to isolate the active componds. Popoola et al., 2016 reported that the ethanolic extracts of Garcinia kola stem bark, Uvaria chamae roots and Olax subscorpioidea roots produced significant time and dose dependent reduction in carrageenan-induced inflammation during the 6 hour study. For G. kola maximum inhibition of $73 \%$ was observed at $200 \mathrm{mg} / \mathrm{kg}$, for $U$. chamae $86.7 \%$ produced by $100 \mathrm{mg} / \mathrm{kg}$ and for $O$. subscorpioidea at $92.31 \%$ produced by $400 \mathrm{mg} / \mathrm{kg}$ bw 6 hours post carrageenan injection.

In Table 3 is presented the results of the qualitative phytochemical analysis of A. bakerianus root extract. The following relevant classes of phytochemicals were detected in the root extract: alkaloids, glycosides, reducing sugars, terpenoids, saponins, phytosterols, simple phenols, polyphenols, flavonoids, tannins, phlobatannins, anthocyanins, betacyanins, coumarins and amino acids. All these compounds have been reported to exhibit antiinflammatory activity (Kosala et al., 2018; Yoon \& Baek, 2005; Popoola et al., 2016; Agnihotri et al., 2010; Rodrigues et al., 2016; Owolabi et al., 2018; Aquila et al., 2009; Sayyah et al., 2004; Street et al., 2013; Bribi et al., 2015; Zhang et al., 2018; Su et al., 2019; Garcia et al., 1999). These compounds have also been found in roots of other Asteraceae species (Ugwoke et al., 2017; Senguttuvan et al., 2014; Cheng \& Shao, 1993; Kwon et al., 2003; Wang et al., 2003; Liu et al., 2007; Su et al., 2019). Most of the phytochemicals identified in the A. bakeriaus root extract were polyphenolic in nature and as phenolics, they are known antioxidants (Zelice da Cruz de Moraes et al., 2020; Senguttuvan et al., 2014). Antioxidants are known to exhibit antiinflammatoriy activity (Yoon and Baek, 2005; Wu et al., 2006; Zelice da Cruz de Moraes et al., 2020; Barragán-Zarate et al., 2020). Antioxidant phytochemicals in plant extracts are repored to reduce oxidative stress resulting from neutrophil activity during inflammation by possibly increasing the activity of antioxidant enzymes, such as superoxide dismutase (SOD), catalase (CAT), glutathione peroxidase (GPX), and glutathione (GSH) and by reducing ROS generation by neutrophils (Akamatsu et al., 1991; Barragán-Zarate et al., 2020). Alkaloids are said to reduce the intensity of oedema caused by carrageenan by inhibiting vascular permeability induced by histamine (Perez, 2001; Owolabi et al 2018). Some alkaloids may also prevent inflammation through blocking the metabolic pathway of arachidonic acid (Barik et al., 1992; Ullah et al., 2014) and also through inhibition of production of nitric oxide, IL-6 and through down-regulating messenger ribonucleic acid expression of proinflammatory key players such as IL-6, IL-1 $\beta$, inducible nitric oxide synthase, TNF- $\alpha$, and cyclooxygenase-2 (Bribi et al., 2015). Compounds with aromatic rings and alcohol groups as seen in phenols and polyphenols (such as coumarins, flavonoids, tannins, phlobatannins, anthocyanins, betacyanins) have been known to modulate inflammation at different levels by decreasing the production of reactive nitrogen and oxygen species (Kim et al., 2006; Arulselvan et al., 2016; Hassimotto et al., 2013), limiting the activity of NF$\kappa \mathrm{B}$, iNOS and COX-2, limiting mRNA expression levels of nitric oxidesynthase (iNOS) and cyclooxygenase-2 (COX-2) in cells (Khan et al., 2015; Ahad et al., 2014; Rizvi et al., 2014), suppressing inflammatory chemokines and cytokines such as interleukin -6 (IL-6), TNF- $\alpha$, IL-1 $\beta$ synthesis, as well as controlling pathways for $\mathrm{NF}-\kappa \beta$ signaling (Mansouri et al., 2015; Arulselvan et al., 2016; Santangelo et al., 2007; González et al., 2011; Ghorbanzadeh et al., 2015; Ben Saad et al., 2017; Rizvi et al., 2014). Phenolic glycosides and kaempferol glycosides are reported to inhibit nitric oxide (NO) production and nitrite production which is the stable end product of $\mathrm{NO}$ and $\mathrm{TNF}-\alpha$ (Agnihotri et al., 2010; Liu et al., 2016; Hien et al., 2018). Terpenoids and saponins have been reported to exhibit antiinflammatory effects through nuclear factor kappa B $(\mathrm{NF} \kappa \mathrm{B})$-inhibiting mechanisms and inhibition of production of pro-inflammatory cytokines and iNOS production (de las Heras \& Hortelano 2009; Kim et al., 2009; Owolabi et al., 2018). Saponins consist of triterpenoids or steroidal aglycons and oligosaccharide substituents (Kosala et al., 2018). Triterpenoids may perform their antiinflammatory action by reducing the number of cells that expresses inducible nitric acid synthase (iNOS) (Lucetti et al., 2010; Owolabi et al., 2018) or by inhibiting the production of nitric oxide (NO) through decreasing iNOS expression (Schmide et al., 2009; Owolabi et al 2018). Terpenoids in general have a high tendency to inhibit inflammatory processes by 

in Rats

inhibiting the production of pro-inflammatory cytokines and iNOS production (Kim et al., 2009; Owolabi et al., 2018). Phytosterols are known to reduce inflammation through the inhibition of Phospholipase A2, which hydrolyses arachidonic acid from membrane phospholipids. This prevents the formation of prostaglandins and leukotrienes via the cyclooxygenase and lipooxygenase pathways respectively, and this could result in reduction of inflammation (Yuan et al., 2019). Phytosterols, just like polyphenols, have also been reported to possess anti-inflammatory activity by decreasing various mediators of inflammation such as prostaglandins, NO, cytokines TNF- $\alpha$ IL-6, and IL-1 (Rizvi et al., 2014).

The observed anti-inflammatory activity of the $A$. bakerianus root extract in this study could therefore be ascribed to terpenoids, alkaloids, simple phenols including coumarins and polyphenols, including flavonoids and tannins as well as glycosides among other bioactive compounds acting either as distinct entities or a combination of these phytochemicals acting synergistically (Barragán-Zarate et al., 2020; Popoola et al., 2016). Kosala et al., 2018 attributed the antiiflammatory activity of the methanolic extract of Coptosapelta flavescens roots that they observed to the presence of polyphenols, terpenoids, steroids, anthraquinones and saponins. In a study of the antiinflammatorry activity of ethanolic extracts roots of Cichorium intybus (chicory roots) by Rizvi et al., 2014, the observed anti-inflammatory activity was attributed to the presence of polyphenols, flavonoids, sterols, glycosides, tannins, and terpenoids reported in chicory roots (Street et al., 2013).

Th findings of this study on A. bakerianus extract suggest that the bioactive phytochemical constituents in the crude extract of $A$. bakerianus roots suppressed all the phases of acute inflammation, with the inhibition being more effective in the late phase, probably by interfering with the release and/or activity of the chemical mediators, such as histamine, serotonin, bradykinin, prostaglandins. Similar to the mechanisms of action of other NSAIDs, both the therapeutic and adverse event profiles of indomethacin are caused by decreased production of prostaglandins (Lucas 2016). For this purpose, ethnobotanical studies represent an increasingly attractive approach for applying indigenous knowledge of plant use to modern societies, with the final aim of developing new remedies.

\section{Conclusion}

The anti-inflammatory activity of $A$. bakerianus root extract in this study was statistically similar in efficacy to that of the reference drug indomethacin, a
COX-1 and COX-2 inhibitor. All doses of $A$. bakerianus root extract used in this study statistically had the same efficacy as the reference drug indomethacin at all the time intervals of the study. Administration of A. bakerianus root extract inhibited the carrageenan-induced inflammatory oedema starting from the first hour after aseptic subcutaneous injection of carrageenan into the rat hind paw and during all phases of inflammation. The inhibition of inflammation was attributed to the presence of various phytochemical classes in the extract, most of which are known to exhibit antioxidant activity. These detected phytochemicals might have reduced the plasma concentrations of pro-inflammatory mediators of the early, intermediate and late phase mediators as well as oxidant species in all phases. The present study confirms the efficacy of the root extract of $A$. bakerianus as an efficient acute phase anti-inflammatory medication, traditionally used by Basotho in the treatment of various types of inflammation.

\section{Acknowledgements}

This research was funded by the Research and Conferences Committee of the National University of Lesotho.

\section{Conflict of interests}

There is no conflict of interests among the authors.

\section{References}

1. Agnihotri S, Kakode S, Agnihotri A. 2010. An overview on antinflammatory properties and chemo-profiles of plants used in traditional medicine. Indian Journal of Natural Products and Resources. 1 (2): 150-167.

2. Ahad A, Ganai AA, Mujeeb M, Siddiqui WA. 2014. Ellagic acid, an NF-KB inhibitor, ameliorates renal function in experimental diabetic nephropathy. Chemico- Biological Interactions. $\quad 219 \quad$ (5): $\quad$ 64-75. https://doi.org/10.1016/j.cbi.2014.05.011

3. Akamatsu H, Miyachi Y, Asada Y, Niwa Y. 1991. Effects of azelastine on neutrophil chemotaxis, phagocytosis and oxygen radical generation. The Japanese Journal of Pharmacology. https://doi.org/10.1254/jjp.57.583.

4. Amala Hazel AM, Pattarayan R, Banumathi V. 2018. Acute Anti-inflammatory activity of Eraippu Noi Chooranam on carrageenan induced paw edema in wistar albino rats. International Journal of Current Research in Medical Sciences. $\quad 4(1)$ : 170-175. https://dx.doi.org/10.22192/ijcrms.2018.04.01.021

5. Ambriz-Pérez DL, Leyva-López L, Gutierrez-Grijalva EP, Heredia JB. 2016. Phenolic compounds: Natural alternative in inflammation treatment. A review. Cogent Food and $\begin{array}{ll}\text { Agriculture. } & 2(1) \text { : } 14\end{array}$ https://doi.org/10.1080/23311932.2015.1131412

6. Aquila S, Giner RM, Recio MC, Spegazzini ED, Rios JL. 2009. Anti-inflammatory

activity of flavonoids from Cayaponia tuyuya roots. Journal of Ethnopharmacology. 121, 333-337.

7. Arulselvan P, Fard MT, Tan WS, Gothai S, Fakurazi S, Norhaizan ME, Kumar SS. 2016. Role of antioxidants and natural products in inflammation. Oxidative Medicine and 

in Rats

Cellular $\quad$ Longevity. $1: 1-16$. https://doi.org/10.1155/2016/5276130.

8. Bamgbose SO, Noamesi BK. 1981. Studies on cryptolepine II: inhibition of carrageenan-induced edema by cryptolepine. Planta Medica. 41(4): 392-396. https://doi.org/10.1055/s2007-971733.

9. Bandaranayake WM. 2006. Quality control, screening, toxicity and regulation of herbal drugs. pp 25-55. In: Modern Phytomedicine: Turning Medicinal Plants into Drugs 2006. Editors: Iqbal Ahmad, Farrukh Aqil, Mohammad Owais. Copyright (C) 2006 Wiley-VCH Verlag GmbH \& Co. KgaA. https://doi.org/10.1002/9783527609987.ch2

10. Barik BR, Bhowmik T, Dey AK, Patra A, Chatterjee, A, Joy S, Susan T, Alam M,

Kundu AB. 1992. Premnazole and isoxazole alkaloid of Premna integrifolia and Gmelina arborea with antiinflammatory activity. Fitoterapia. 63(4):295-299.

11. Barragán-Zarate GS, Lagunez-Rivera L, Solano R, PinedaPeña EA, Landa-Juárez AY, Chávez-Piña AE, CarranzaÁlvarez C, Hernández-Benavides DM. 2020. Prosthechea karwinskii, an orchid used as traditional medicine, exerts anti-inflammatory activity and inhibits ROS. Journal of Ethnopharmacology.

253:112632. https://doi.org/10.1016/j.jep.2020.112632

12. Ben IO, Etim OE, Udo NM. 2016. Anti-inflammatory effects of Napoleona imperialis P. Beauv. (Lecythidaceae) on rat model of inflammation. Indian Journal of Health Sciences. 9:89-95. https://doi: 10.4103/2349-5006.18368.

13. Ben Saad LA, Kim KH, Quah CC, Kim WR, Shahimi M. 2017. Anti-inflammatory potential of ellagic acid, gallic acid and punicalagin A\&B isolated from Punica granatum. BMC Complementary and Alternative Medicine. 17: 47-56. https://doi.org/10.1186/s12906-017-1555-0

14. Bharathi T, Udayakumar R. 2019. Phytochemical screening and nutrient content analysis of stem and root of Tridax procumbens Lin. International Journal of Research $\begin{array}{lll}\text { Granthaalaya. } & 7(8): & 470-477 .\end{array}$ https://doi.org/10.5281/zenodo.3401617

15. Birhane R, Shibeshi W, Asres K. 2014. Evaluation of analgesic and anti-inflammatory activities of the root extracts of Indigofera spicata F. in mice. Ethiopian Pharmaceutical Journal. 30: 65-76. http://dx.doi.org/10.4314/epj.v30i2.1

16. Bribi N, Algieri F, Rodriguez-Nogales A, Garrido-Mesa J,Vezza T, Maiza F, Utrilla MP, Rodriguez-Cabezas ME, Galvez, J. 2015. Antinociceptive and anti-inflammatory effects of total alkaloid extract from Fumaria capreolata. Evidence- Based Complementary and Alternative Medicine. https://doi.org/10.1155/2015/736895

17. Calixto JB, Campos MM, Otuki MF, Santos ARS. 2004. Anti-inflammatory compounds of plant origin. Part II. Modulation of pro-inflammatory cytokines, chemokines and adhesion molecules. Planta Medica.70(2): 93-103._doi: $10.1055 / \mathrm{s}-2004-815483$

18. Cheng D, ShaoY. 1993.Terpenoid glycosides from the roots of Aster tataricus. Phytochemistry. 35(1):173-176. https://doi.org/10.1016/S0031-9422(00)90528-4

19. Danya U. 2017. In vivo anti-inflammatory activity of the endemic medicinal plant Caralluma sarkariae R.Br. using carrageenan induced paw oedema in swiss albino mice. Journal of Medicinal Plants Studies. 5(2):133-135.

20. de las Heras B, Hortelano S. 2009. Molecular basis of the anti-inflammatory effects of terpenoids. Inflammation \& Allergy Drug Targets. 8(1):28-39. https://doi.org/10.2174/187152809787582534

21. Di Rosa M, Giroud JP, Willoughby DA. 1971. Studies on the mediators of the acute inflammatory response induced in rats in different sites by carrageenan and turpentine. The Journal of Pathology. 104:15-29. https://doi.org/10.1002/path.1711040103

22. Di Rosa M, Sorreatino L. 1968. The mechanism of the inflammatory effects of carrageenan. European Journal of
Pharmacology. 4(3): 340-342. https://doi.org/10.1016/00142999(68)90103-9

23. El-Shitany NA, El-Bastawissy EA, El-desoky K. 2014. Ellagic acid protects against carrageenan-induced acute inflammation through inhibition of nuclear factor kappa B, inducible cyclooxygenase and proinflammatory cytokines and enhancement of interleukin-10 via an antioxidant mechanism. International Immunopharmacology 19(2): 290 299. https://doi.org/10.1016/j.intimp.2014.02.004.

24. Falodun A, Okunrobo LO, Uzoamaka N. 2006. Phytochemical screening and anti-inflammatory evaluation of methanolic and aqueous extracts of Euphorbia heterophylla Linn (Euphorbiaceae). African Journal of Biotechnology 5 (6):529-531.

25. Fernandes G, Banu J. 2012. Medicinal properties of plants from the genus Cissus: A-review. Journal of Medicinal Plants Research 6(16):3080-3086.

26. Ganesh G, Saurabh M, Sarada NC. 2013. Antioxidant and anti-inflammatory activities of the methanolic leaf extract of traditionally used medicinal plant Mimusops elengi L. Journal of Pharmaceutical Science and Research. 5(6):125-130.

27. García MD, M T Sáenz MT, Gómez MA, Fernández MA. 1999. Topical antiinflammatory activity of phytosterols isolated from Eryngium foetidum on chronic and acute inflammation models. Phytotherapy Research. 13(1):78-80. https://doi.org/10.1002/(SICI)1099 1573(199902)13:1<78::AID-PTR384>3.0.CO;2-F

28. Ghorbanzadeh B, Mansouri M, Hemmati A, Naghizadeh B, Mard S, Rezaie A. 2015. A study of the mechanisms underlying the anti-inflammatory effect of ellagic acid in carrageenan-induced paw edema in rats. Indian Journal of Pharmacology. 47, 292-298. https://doi.org/10.4103/02537613.157127

29. González R, Ballester I, López-Posadas R, Suárez MD, Zarzuelo A, Martínez-Augustin O, Sánchez De Medina F. 2011. Effects of flavonoids and other polyphenols on inflammation. Critical Reviews in Food Science and Nutrition. 51(4): 331-362, https://doi.org/10.1080/10408390903584094

30. Gul R, Jan SU, Faridullah S, Sherani S, Jahan N. 2017. Preliminary phytochemical screening, quantitative analysis of alkaloids, and antioxidant activity of crude plant extracts from Ephedra intermedia Indigenous to Balochistan. Hindawi The Scientific World Journal. Volume 2017: Article ID 5873648, 7 pages. Pp1-7. https://doi.org/10.1155/2017/5873648

31. Hassimotto NM, Moreira V, do Nascimento NG, Souto PC, Teixeira C, Lajolo FM. 2013. Inhibition of carrageenaninduced acute inflammation in mice by oral administration of anthocyanin mixture from wild mulberry and cyanidin-3glucoside. Biomedicine Research International. 2013(4):146716. https://doi:10.1155/2013/146716.

32. Hien TTT, Quang TH, Tai BH, Nhiem NX, Yen PH, Yen DTH, Cuong Le Canh V, Chul Kim Y-C, Oh H, Minh CV and Kiem PV. 2018. Iridoid glycosides and phenolic glycosides from Buddleja asiatica with anti-inflammatory and cytoprotective activities. Natural Product Communications 13(1):1-4.

33. Hussein SZ, Yusoff KM, Makpol S, Yusof YAM. 2012. Gelam honey inhibits the production of proinflammatory mediators NO, PGE2, TNF- $\alpha$, and IL-6 in carrageenaninduced acute paw edema in rats. Evidence-based Complementary \& Alternative Medicine._2012: 109636. p 113. https://doi.org/ 10.1155/2012/109636

34. Hutchings A, van Staden J. 1994. Plants used for stressrelated ailments in traditional Zulu, Xhosa, Sotho Medicine. Part1: Plants used for headaches. Journal of Ethnopharmacology. 43: 89-124.

35. Ishola IO, Agbaje EO, Adeyemi OO, Shukla R. 2014. Analgesic and anti-inflammatory effects of the methanol root extracts of some selected Nigerian medicinal plants. 
Pharmaeutical Biology. 52 (9): 1208-1216.

https://doi.org/10.3109/13880209.2014.880487

36. Iwueke AV, Nwodo OFC, Okoli CO. 2006. Evaluation of the anti-inflammatory and analgesic activities of Vitex doniana leaves. African Journal of Biotechnology. 5 (20): 1929-1935.

37. Karin M, Ben-Neriah, Y. 2000. Phosphorylation meet ubiquitination: the control of NF-kB Activity. Annual Review of Immunology.18: 621-663. https://doi.org/10.1146/annurev.immunol.18.1.621

38. Kaur S, Jaggi R. 2010. Antinociceptive activity of chronic administration of different extracts of Terminalia bellerica Roxb. and Terminalia chebula Retz. fruits. Indian Journal of Experimental Biology. 48:925-930.

39. Khakimov ZZ, Rakhmanov AK, Mavlanov SR. 2019. Study of the influence of dry extract of medicinal plants on the course of carrageenan-induced inflammation. American Journal of Medicine and Medical Sciences. 9(8): 307-310. https://doi.org/10.5923/j.ajmms.20190908.07

40. Khan S, Shehzad O, Cheng M-S, Li R-J, Kim YS. (2015), Pharmacological mechanism underlying anti-inflammatory properties of two structurally divergent coumarins through the inhibition of pro-inflammatory enzymes and cytokines. Journal of Inflammation. 12(47):1-11. https://doi.org/10.1186/s12950-015-0087-y

41. Kim SH, Jun CD, Suk K, Choi BJ, Lim H, Park S, Lee SH, Shin HY, Kim DK, Shin TY. 2006. Gallic acid inhibits histamine release and pro-inflammatory cytokine production in mast cells. Toxicological Sciences. 91(1):123-131. https://doi.org/10.1093/ toxsci/kfj063

42. Kim JY, Shin JS, Ryu JH, Kim SY, Cho YW, Choi JH, Lee KT. 2009. Anti-inflammatory effect of anemarsaponin B isolated from the rhizomes of Anemarrhena asphodeloides in LPS-induced RAW 264.7 macrophage is mediated by negative regulation of the nuclear factor-kappaB and $\mathrm{p} 38$ pathways. Food and Chemical Toxicology. 47(7):1610-7. https://doi.org/10.1016/j.fct.2009.04.009

43. Kosala K, Widodo MA, Santoso S, Karyono S. 2018. In vitro and in vivo anti-inflammatory activities of Coptosapelta flavescens Korth root's methanol extract. Journal of Applied Pharmaceutical Science. 8(09): 042-048. https://doi.org/10.7324/JAPS.2018.8907

44. Kulinsky VI. 2007. Biochemical aspects of inflammation. Biochemistry Moscow. 72:595-607. https://doi.org/10.1134/S0006297907060028.

45. Kumar T, Jain V. 2014. Antinociceptive and antiinflammatory activities of Bridelia retusa methanolic fruit extract in experimental animals. Scientific World Journal. 2014:890151. 12 pages. https://doi.org/10.1155/2014/890151

46. Kwon HC, Cho OR, Lee KC, Lee KR. 2003. Cerebrosides and terpene glycosides from the root of Aster scaber. Archives of Pharmacal Research. 26(2):132-137. https://doi.org/10.1007/BF02976658

47. Liu H, Li B, Jiang P, Zhong Y, Zhang D, Liu H, Wan P, Lai X, Liu B, Chen J. 2016. Anti-diabetes and antiinflammatory activities of phenolic glycosides from Liparis odorata. Medicinal Chemistry. 6:500-505. https://doi.org/ 10.4172/2161-0444.1000390.

48. Liu K-Y, Zhang T-J, Gao W-Y, Liu H-J. (2007). Phenolic compounds isolated from root and rhizoma of Aster tataricus. Chinese Traditional and Herbal Drugs. 38(12):1793-1795.

49. Lucas S. 2016. The pharmacology of indomethacin. Headache-The Journal of Head and Face Pain. 56(2): 436446. https://doi.org/10.1111/head.12769

50. Lucetti DL, Lucetti ECP, Bandeira MM, Veras HNH, Silva AH, Leal LAM, Lopes AA, Alves VCC, Silva GS, Brito GA, Viana GB. 2010. Anti-inflammation effects and possible mechanism of action of lupeol acetate isolated from Himatanthus drasticus (Mart.) plumel. Journal of Inflammation. 7:60-70. https://doi.org/10.1186/1476-9255-760
51. Magama S, Asita OA. 2017. Evaluation of Chenopodium album Linn. crude methanolic leaf extract for central antinociceptive activity in albino mice using the hot plate test. International Journal of Sciences. 6(6):36-44 https://doi.org/10.18483/ijSci.1310.

52. Mansouri MT, Hemmati AA, Naghizadeh B, Mard SA, Rezaie A, Ghorbanzadeh B. 2015. A study of the mechanisms underlying the anti-inflammatory effect of ellagic acid in carrageenan-induced paw edema in rats. Indian Journal of Pharmacology. 47(3):292-298. https://doi.org/10.4103/0253-7613.157127

53. Middleton E. 1998. Effect of plant flavonoids on immune and inflammatory cell function. In: Manthey J.A., Buslig B.S (eds) Flavonoids in the Living System. Advances in Experimental Medicine and Biology. 439:175-182. Springer, Boston, MA. https://doi.org/10.1007/978-1-4615-5335-9_13

54. Moteetee A, Seleteng-Kose L. 2017. A review of medicinal plants used by the Basotho for treatment of skin disorders: their phytochemical, antimicrobial, and anti-inflammatory potential. African Journal of Traditional, Complementary and $\begin{array}{llll}\text { Alternative } & \text { Medicines. } & \text { (5): } 121-137\end{array}$ https://doi.org/10.21010/ajtcam.v14i5.16

55. Nathan C. 2002. Points of control in inflammation. Nature. 420(6917):846-852.

56. N'Goka V, Nsonde Ntandou GF, N'Goka V, Boumba SL, Abena A.A. 2018. Chemical screening, acute toxicity and analgesic effect of the aqueous extracts of Vitex madiensis Oliv. (Lamiaceae-Viticoïdeae) and Phytolacca dodecandra L'Hérit. (Phytolaccaceae) leaves. International Journal of Sciences. 7(1):1-9. https://doi.org/10.18483/ijSci.1261

57. Nguyen TH, Nachtergael A, Nguyen TM, Cornet V, Duez P, Mullere M, Huong DTL, Kestemonta P. 2020. Antiinflammatory properties of the ethanol extract from Clerodendrum cyrtophyllum Turcz based on in vitro and in vivo studies. Journal of Ethnopharmacology 254: 112739. https://doi.org/10.1016/j.jep.2020.112739

58. Nsonde Ntandou GF, Bassoueka DJ, Banzouzi JT , Etou Ossibi AW, Elion Itou RDG., Makambila MC, Ramos S, Benoit-Vical F, Abena AA, Ouamba JM. 2015. Assessment of Cassia siamea stem bark extracts toxicity and stability in time of aqueous extract analgesic activity. African Journal of Pharmacy and Pharmacology 9(41): 988-994. DOI: 10.5897/AJPP2009.138.

59. OECD. 2002. Test No. 423: Acute Oral toxicity - Acute Toxic Class Method, OECD Guidelines for the Testing of Chemicals, Section 4, OECD Publishing, Paris, https://doi.org/10.1787/9789264071001-en

60. Oguntibeju OO. 2018. Medicinal plants with antiinflammatory activities from selected countries and regions of Africa. Journal of Inflammation Research. 11: 307-317. https://doi.org/10.2147/JIR.S167789.

61. Owolabi OO, James DB, Sani I, Andongma BT, Opeoluwa O, Fasanya OO, Kure B. 2018. Phytochemical analysis, antioxidant and anti-inflammatory potential of Feretia apodanthera root bark extracts. BMC Complementary and Alternative Medicine. https://doi.org/10.1186/s12906-017-2070-z

62. Panthong A, Supraditaporn W, Kanjanapothi D, Taesotikul T, Reutrakul V. 2007. Analgesic, anti-inflammatory and venotonic effects of Cissus quadrangularis Linn. Journal of Ethnopharmacology. 110: 264-270.

63. Perez RM. 2001. Anti-inflammatory activity of compounds isolated from plants. Scientific World Journal. 1:713-84.

64. Ponmathi SA, Evanjaline M, Muthukumarasamy S, Mohan V. 2017. Evaluation of antiinflammatory activity of ethanol extracts of Barleria courtallica Nees (Acanthaceae). International Journal of Pharmacognosy and Phytochemical Research. $\quad 9(2)$ : 245-247. https://doi.org/10.25258/phyto.v9i2.8070

65. Popoola TD, Awodelea O, Omisanyaa A, Obia N, Umezinwaa C, Fatoku AA. 2016. Three indigenous plants used in anti-cancer remedies, Garcinia kola Heckel (stem 

in Rats

bark), Uvaria chamae P. Beauv. (root) and Olax subscorpioidea Oliv. (root) show analgesic and antiinflammatory activities in animal models. Journal of Ethnopharmacology. $\quad$ 194: 440-449. https://doi.org/10.1016/j.jep.2016.09.046.

66. Prasad DMR, Izam A, Khan MR. 2012. Jatropha curcas: Plant of medical benefits. Journal of Medicinal Plants Research. Vol. 6(14): 2691-2699.

67. Rajanandhini M, Musthafa M. 2017. Pharmacological evaluation of antiinflammatory activity of Pancha Pashana Chendhuram against carrageenan induced paw edema in Rats. International Journal of Current Research in Medical Sciences. $\quad 3(8)$ : 124-129. https://dx.doi.org/10.22192/ijcrms.2017.03.08.019

68. Rizvi, W, Fayazuddin M, Shariq S, Singh O, Moin S, Akhtar K, Kumar A. 2014. Anti-inflammatory activity of roots of Cichorium intybus due to its inhibitory effect on various cytokines and antioxidant activity. Ancient Science of Life. 34(1):44-49. https://doi:10.4103/0257-7941.150780

69. Rodrigues LB, Martins AOBPB, Cesário FRAS, e Castro FF, de Albuquerque TR, Fernandes MNM, da Silva BAF, Quintans Junior LJ, da Costa JGM, Coutinho HDM, Barbosa R, de Menezes IRA. 2016. Anti-inflammatory and antiedematogenic activity of the Ocimum basilicum essential oil and its main compound estragole: In vivo mouse models. Chemico-Biological Interactions. 257:14-25. http://dx.doi.org/10.1016/j.cbi.2016.07.026

70. Salvemini D, Wang ZQ, Wyatt PS, Bourdon DM, Marino MH, Manning PT, Currie, MG. 1996. Nitric oxide: a key mediator in the early and late phase of carrageenan-induced rat paw inflammation. British Journal of Pharmacology. 118(4): $\quad 829-838$. https://doi.org/10.1111/j.14765381.1996.tb15475.x

71. Samad TA. 2001. Interleukin-1 $\beta$-mediated induction of Cox2 in the CNS contributes to inflammatory pain hypersensitivity. Nature. 410:471-475. https://doi.org/10.1038/35068566

72. Santangelo C, Varì R, Scazzocchio B, Benedetto R Di, Filesi C, Masella R. 2007. Polyphenols, intracellular signalling and inflammation. Annali dell'Istituto Superiore di Sanità. 43(4):394-405

73. Sarkhel S. 2016. Evaluation of the anti-inflammatory activities of Quillaja saponaria Mol. saponin extract in mice. Toxicology $\quad$ Reports. $3: 1-3$. https://doi.org/10.1016/j.toxrep.2015.11.006

74. Sarada K, Jothibai, RM, Mohan VR. 2012. Antiinflammatory activity of ethanol extracts of leaf and bark of Naringi crenulata (Roxb.) Nicolson. International Journal of Pharmceutical Science and Research. 3(11): 4540-4544.

75. Sathiyabalan G, Evanjaline MR, Muthukumarasamy S, Mohan VR. 2018. Anti-inflammatory activity of whole plant of Beloperone plumbaginifolia (Acanthaceae). International Journal of Pharmaceutical Sciences and Research. 9(1): 328331. https://doi: 10.13040/IJPSR.0975-8232.9(1).328-31

76. Sayyah M, Hadidi N, Kamalinejad M,. 2004. Analgesic and anti-inflammatory

activity of Lactuca sativa seed extract in rat. Journal of Ethnopharmacology. 92(2-3):325-329. https://doi.org/10.1016/j.jep.2004.03.016

77. Schmide D, Gruber M, Woehs F, Prinz S, Etzlstorfer B, Prucker C, Fuzzati N, Kopp B, Moeslinger T. 2009. Inhibition of inducible nitric oxide synthesis by Cimifuga racemosa (Actaea racemosa, black cohosh) extracts in LPS stimulated RAW 264.7 macrophages. Journal of Pharmacy and Pharmacology. 61(8):1089-1096. https://doi: 10.1211/jpp/61.08.0013.

78. Seleteng-Kose, L, Moteetee A, Van Vuuren S. 2019. Medicinal plants used for the treatment of sexually transmitted infections in the Maseru District, Lesotho: Antimicrobial validation, phytochemical and cytotoxicity studies. South African Journal of Botany. 122:457-466. https://doi.org/10.1016/j.sajb.2019.01.035
79. Senguttuvan J, Paulsamy S, Karthika K. 2014. Phytochemical analysis and evaluation of leaf and root parts of the medicinal herb, Hypochaeris radicata L. for in vitro antioxidant activities. Asian Pacific Journal of Tropical Biomedicine. $\quad 4(1): \quad$ S359-S36. https://doi.org/10.12980/APJTB.4.2014C1030.

80. Shale TL, Stirk WA, van Staden J. 1999. Screening of medicinal plants used in Lesotho for anti-bacterial and antiinflammatory activity. Journal of Ethnopharmacology. 67(3):347-354. https://doi.org/10.1016/S03788741(99)00035-5

81. Sidhapuriwala J, Li L, Sparatore A, Bhatia M, Moore PK. 2007. Effect of S-diclofenac, a novel hydrogen sulfide releasing derivative, on carrageenan induced hind paw oedema formation in the rat. European Journal of Pharmacology. 569(1-2): 149-154. https://doi.org/ 10.1016/j.ejphar.2007.05.003

82. Street RA, Sidana J, Prinsloo G. 2013. Cichorium intybus: Traditional uses, phytochemistry, pharmacology, and toxicology. Evidence-Based Complementary and Alternative Medicine. 2013: https://doi.org/10.1155/2013/579319.

83. Su X-D, Jang H-J, Wang C-Y, Lee SW, Rho M-C, Kim YH, Yang SY. 2019. Anti-inflammatory potential of saponins from Aster tataricus via NF- $\mathrm{B} / \mathrm{MAPK}$ activation. Journal of Natural Products 82 (5): 1139-1148. https://doi.org/ 10.1021/acs.jnatprod.8b00856

84. Talluri MR, Rao BG, Rao YV. 2016. Anti-Inflammatory Activity of Chrozophora rottleri extracts on carrageenaninduced rat paw edema. International Journal of Pharmacology, Phytochemistry and Ethnomedicine. 3:20-26. https://doi:10.18052/www.scipress.com/IJPPE.3.20

85. Thilagavathi T, Arvindganth R, Vidhya D, Dhivya R. 2015. Preliminary phytochemical screening of different solvent mediated medicinal plant extracts evaluated. International Research Journal of Pharmacy. 6(4):246-248. http://dx.doi.org/10.7897/2230-8407.06455

86. Ugwoke CEC, Orji J, Anze SPG, Ilodibia CV. 2017 Quantitative Phytochemical Analysis and Antimicrobial Potential of the Ethanol and Aqueous Extracts of the Leaf, Stem and Root of Chromolaena odorata (Asteraceae) International Journal of Pharmacognosy and Phytochemical Research. 9(2); 207-214. DOI: 10.25258/phyto.v9i2.8064

87. Ullah HM, Zaman S, Juhara F, Akter L, Tareq SM, Masum EH, Bhattacharjee R. 2014. Evaluation of antinociceptive, invivo \& in-vitro anti-inflammatory activity of ethanolic extract of Curcuma zedoaria rhizome. BMC Complementary and Alternative Medicine. 22(14):346. https://doi: 10.1186/1472-6882-14-346.

88. Van Wyk BE, van Oudtshourch B, Gericke N. 1997. Medicinal Plants of South Africa, $1^{\text {st }}$ Edition, Briza Publications, South Africa, pp 50.

89. Wang G-Y, Wu T, Lin P-C, Chou G-X, Wang Z-T. 2003. Phenolic compounds isolated from rhizoma of Aster tataricus. China Journal of Chinese Materia Medica. 28(10):946-8.

90. Winter CA, Risley EA, Nuss GW. 1962. Carrageenininduced edema in hind paw of the rat as an assay for antiinflammatory drugs. Proceedings of the Society for Experimental Biology and Medicine. 111(3), 544-547. https://doi.org/10.3181/00379727-111-27849

91. Wu Y, Zhou C, Song L, Li X, Shi S, Mo J, Chen H, Bai H, Wu X, Zhao J, Zhang R, Hao X, Sun H, Zhao Y. 2006. Effect of total phenolics from Laggera alata on acute and chronic inflammation models. Journal of Ethnopharmacology. 108(2): 243-250. https://doi.org/10.1016/j.jep.2006.05.017

92. Xiong Q, Tezuka Y, Kaneko T, Li H, Tran LQ, Hase K, Namba T, Kadota S. 2000. Inhibition of nitric oxide by phenylethanoids in activated macrophages. European Journal $\begin{array}{llll}\text { of } & \text { Pharmacology. } 400 & \text { (1): } 137-144 .\end{array}$ https://doi.org/10.1016/s0014-2999(00)00354-x 
Evaluation of Aster bakerianus Burtt Davy ex C.A. Sm. Crude Root Extract for Acute Antiinflammatory Activity in Rats

93. Yamamoto Y, Gaynor RB. 2001. Therapeutic potential of inhibition of the NF-kappaB pathway in the treatment of inflammation and cancer. The Journal of Clinical Investigation. $\quad 107(2)$ : $135-142$. https://doi.org/10.1172/JCI11914

94. Yoon J-H, Baek SJ. 2005. Molecular targets of dietary polyphenols with anti-inflammatory properties. Yonsei Medical Journal. 46(5):585-596. https://doi.org/10.3349/ymj.2005.46.5.585

95. Yuan L, Zhang F, Shen M, Jia S, Xie J. 2019. Phytosterols suppress phagocytosis and inhibit inflammatory mediators via ERK Pathway on LPS-triggered inflammatory responses in RAW264.7 macrophages and the correlation with their $\begin{array}{lll}\text { structure. } & \text { Foods. }\end{array}$ https://doi.org/10.3390/foods8110582

96. Zahra Z, Khan MR, Shah SA, Maryam S, Majid M, Younisa T, Sajid M. 2020. Vincetoxicum arnottianum ameliorate inflammation by suppressing oxidative stress and pro-inflammatory mediators in rat. Journal of Ethnopharmacology 252: 112565 https://doi.org/10.1016/j.jep.2020.112565

97. Zelice da Cruz de Moraes S, Shan A, Oliveira Melo MA, Pereira da Silva J, Rocha Santos Passos F, de Souza Graça A, Araújo BS, Quintans J, Quintans Júnior LJ, Oliveira Barreto E, Brandão GC, Estevam C. 2020. Antinociceptive and antiinflammatory effect of Poincianella pyramidalis (Tul.) L.P. Queiroz. Journal of Ethnopharmacology. 254: 112563. https://doi.org/10.1016/j.jep.2020.112563

98. Zhang T-T, Hu T, Jiang J-G, Zhao J-W, Zhu W 2018. Antioxidant and anti-inflammatory effects of polyphenols extracted from Ilex latifolia Thunb. Royal Society of Chemistry Advances. 8: 7134-7141. https://doi.org/10.1039/C7RA13569F. 